\title{
Molecular characterization of contagious ecthyma virus (CEV) isolated from goat and cross-protection studies')
}

\author{
VELI GULYAZ, MUSTAFA HASOKSUZ*, METING BULUT**, FAHRIYE SARAÇ**
}

\begin{abstract}
Ministry of Agriculture and Forestry, General Directorate of Food and Control, Çankaya, Ankara 06800, Turkey *Istanbul University Cerrahpasa, Faculty of Veterinary Medicine, Department of Virology, Hadimkoy, Istanbul 34320, Turkey **Pendik Veterinary Control Institute, Pendik, Istanbul 34890, Turkey
\end{abstract}

\section{Gulyaz V., Hasoksuz M., Bulut M., Saraç F. \\ Molecular characterization of contagious ecthyma virus (CEV) isolated from goat and cross-protection studies}

Summary

Contagious ecthyma (CE) is a zoonotic viral infection caused by the Parapoxvirus in sheep and goats which is classified in the family of Poxviridae. In this study, the Penorf CE vaccine strain that originated from lambs (PKCE1 strain) and three CE strains (O-CEV1, O-CEV2, O-CEV3) originated from kids were used for molecular characterization and cross-protection studies. A phylogenetic similarity has been investigated by comparing the B2L gene of CE viruses originated from kids and lambs. It was observed that the isolates O-CEV1 and O-CEV2 had a similar DNA sequence $(\mathbf{1 0 0 \%})$ whereas the other isolate, O-CEV3 had a different DNA sequence from the others, and the proportion of the difference between them was $2.6 \%$ as stated in the similarity index. The phylogenic evaluation revealed that $\mathrm{CE}$ viruses were not species specific and have different genotypes in lambs and kids in Turkey. Penorf vaccine strain which is still known as lamb origin was found to be also kid origin. In the pathogenity studies in kids and lambs, there was no rise in the body temperatures of lambs and kids and hyperemia, vesicles and pustules occurred in the scarified skin regions from the second day of the epruvation. In addition to these findings, it was determined that the healing in lesions occurred after the scabs fell off beginning from the $38^{\text {th }}$ to $55^{\text {th }}$ days of the study. At the end of the this study, the presence of CE strains with different pathogenicity properties was revealed. In goats vaccinated with Penorf vaccine, protection to O-CEV3 field isolate has been observed, but not obtained protection to PK-CK1 strain.

As a result, the phylogenic evaluation revealed that $\mathrm{CE}$ viruses were not species specific and have different genotypes in lambs and kids in Turkey. The Penorf vaccine strain, which is still known to be of lamb origin, was found to be of kid origin and it was not seen to protect lambs against $\mathrm{CE}$ disease due to the genomic differences. Therefore, it was concluded from this data that at least a bivalent $\mathrm{CE}$ vaccine containing lamb and kid isolates should be prepared and used for effective immunity against CE infection, especially in lambs and kids.

Keywords: contagious ecthyma, moleculary characterization, pathogenicity, immunization

Contagious ecthyma (Orf) infection caused by Parapoxvirus ovis (PPV) is a viral disease in sheep, goats, deer, and humans $(6,8)$. The contagious ecthyma (CE) virus has a close relationship to the parapoxviruses of cattle, morphologically, immunologically, and gnomically $(5,24)$. The disease can be transmitted by direct contact, drinking water, or feed and is common in sheep and goats, especially during the dry season because of their feeding on dry, hard grass in the pasture. The $\mathrm{CE}$ virus is an epitheliotropic virus that penetrates damaged skin around the mouth and

This project was supported by the Scientific and Technological Research Council of Turkey (TUBITAK) (Project Number: TOVAG-111O398). regenerates in the epidermal keratinocytes (28). The infection is usually acute and seen clinically in the forms of macules, papules, vesicles, pustules, and proliferative lesions in the mouth, nose, gums, oral mucosa, breast, coronary band of the feet, and anus ( 6 , $7,10)$. The lesions in the female sheep and goats are usually seen in the breasts because of suckling of $\mathrm{CE}$ infected lambs and kids. The incubation period varies from 24 to 72 hours in experimental infections. While morbidity rates can reach up to $80-100$, the mortality rate is $1 \%$ in cases without complication and $20-50 \%$ in cases with secondary infections by Cochliomyia Americana and Fusobacterium Tunnicliffle $(19,26)$. 
Live attenuated vaccines are widely used to protect lambs and kids from CE infection. However, in recent studies it has been reported that CE symptoms are observed in different forms in animals vaccinated with $\mathrm{CE}$ vaccine due to genomic differences between $C E$ vaccine and field viruses. Additionally, conventional CE attenuated live vaccines are less effective at preventing the disease at present. This is mainly due to the rapid changes in the genomes of $\mathrm{CE}$ virus vaccine strains during cell culture adaptation, particularly involving the ends of viral genome $(15,24,31)$. CE infection in lambs and kids is seen with widely varying severity in Turkey. The CE vaccine called PENORF is used to combat this disease. CE infection is still observed with varying severity of clinical symptoms in lamb and kid herds vaccinated with $\mathrm{CE}$ vaccine in Turkey.

The aim of this study was to determine the molecular characterization among $\mathrm{CE}$ virus isolates and to find the cross-immunity between field isolates and the vaccine strain in lambs and kids in Turkey.

\section{Material and methods}

CE virus strains. A live attenuated commercial vaccine (PENORF) $\left(\mathrm{E}(\mathrm{P}) \mathrm{CK}_{22}\right)$ and $\mathrm{CE}$ virus isolates (a PK-CK1 strain isolated from a lamb and O-CEV1, O-CEV2 and $\mathrm{O}-\mathrm{CEV} 3$ strains isolated from kids) were used in the pathogenicity and immunization studies.

DNA isolation and DNA cleaning kits. DNA isolation from a virus inoculated cell culture was performed with a High Pure Viral Nucleic Acid Kit (Roche, Cat No: 11858874001) according to the protocols specified in the kit. For cleaning the pre-sequence PCR products, a High Pure PCR Product Purification Kit (Roche, Cat No: 1173267600) was used in accordance with the protocols specified by the manufacturer.

Primers, PCR and sequencing. We selected the DNA sequencing of the whole $\mathrm{B} 2 \mathrm{~L}$ gene of $1137 \mathrm{bp}$ of the $\mathrm{CE}$ virus from the reference genes in the NCBI gene bank using the PrimSelect mode of the DNASTAR gene analysis program and used as sequence primers. The primers used in the study (Tab. 1) were diluted to 20 pmol, and optimization studies were performed in which optimum grades and

Tab. 1. Primers used for DNA sequencing of the B2L gene of CE (ORF) strains

\begin{tabular}{|l|c|l|c|c|}
\hline $\begin{array}{c}\text { Name of } \\
\text { primers }\end{array}$ & Sense & \multicolumn{1}{|c|}{ Sequencing of primers (5-3) } & MER & $\begin{array}{c}\text { Product } \\
\text { length }\end{array}$ \\
\hline OVB2LF & + & TCC CTG AAG CCC TAT TAT TTT TGT G & 25 & 1206 bp \\
\hline OVB2LR & - & GCT TGC GGG CGT TCG GAC CTT C & 22 & \\
\hline B2LF1 & + & AGA ACT CGC CCG CCT GCT AAA AGA & 24 & 660 bp \\
\hline B2LR2 & - & CCC CGG AGT GGT CGA GGT GGA AGT & 24 & \\
\hline B2LF2 & + & CAA GCA CCT GGC CTG GGA CCT CAT & 24 & 713 bp \\
\hline B2LR3 & - & GCT TGC GGG CGT TCG GAC CTT C & 22 & \\
\hline B2LF3 & + & GCA CCG CAT CGA GAA CGC CAA GAA & 24 & 574 bp \\
\hline B2LR4 & - & AGG GAC GCC GCC GCA CAC C & 19 & \\
\hline B2LF4 & + & GAA GAA CTC GCC CGC CTG CTA AAA & 24 & 346 bp \\
\hline B2LR5 & - & GTC CGC GTC CTT GTC CTT GCT CTG & 24 & \\
\hline
\end{tabular}

durations were determined for each primer. Accordingly, $5 \mu \mathrm{l}$ of template DNA, $10 \mu \mathrm{l}$ of $10 \mathrm{X}$ buffer, $1 \mu 1$ of dNTP $(0.8 \mu \mathrm{M}), 1 \mu \mathrm{l}$ of primary $\mathrm{F}$ and primary $\mathrm{R}(20 \mathrm{pmol})$, $0.5 \mu 1$ of Taq DNA Polymerase $(2.5 \mathrm{U})$, and $\mathrm{dd}_{2} \mathrm{O}$ were added to obtain a total volume of $50 \mu$. The mixture was briefly spun and placed in the thermal cycler. Amplification was carried out using initial denaturation for three minutes at $94^{\circ} \mathrm{C}$, followed by 31 cycles as follows: one minute at $94^{\circ} \mathrm{C}, 45$ seconds at $53^{\circ} \mathrm{C}$, one minute at $72^{\circ} \mathrm{C}$; and the final elongation was performed for seven minutes at $72^{\circ} \mathrm{C}$ for 31 cycles. The PCR products were electrophoresed under $100 \mathrm{~V}$ in $2 \%$ agarose gel, and DNA bands were observed in UV medium $(5,12,16,27)$. The DNA sequences and reference DNA sequences of the genes of the $\mathrm{CE}$ viruses obtained from the NCBI Gene Bank were analyzed in the DNASTAR gene analysis program using the Clustal W analysis method to determine their differences as to nucleotides and amino acids. For phylogenetic relationships between the viruses and similarity indices the neighbor-joining method was used.

FLK-BLV-044 cell culture. FLK-BLV-044 (Ovine embryonal kidney cells) (DSMZ No: ACC 153) working seed cells were diluted with DMEM-F12 (Biochrom, Cat No: F 4815) medium containing 10\% FCS (Biochrom, Cat No: $\mathrm{S}-0125$ ) to $3 \times 10^{5} / \mathrm{ml}$ cells and produced as monolayer in $25 \mathrm{~cm}^{2}$ flasks in a $37^{\circ} \mathrm{C}$ incubator containing $5 \% \mathrm{CO}_{2}$ $(3,9,22)$.

Infectivity titers of $\mathrm{CE}$ viruses isolated from lambs and kids. To find the infectivity titers, $100 \mu \mathrm{l}$ of $\mathrm{CE}$ virus isolates were inoculated to FLK-BLV-044 cell cultures and incubated in an oven at $37^{\circ} \mathrm{C}$ in a $5 \% \mathrm{CO}_{2}$ condition. Cells were collected when a $90 \%$ cytopathologic effect (CPE) formation in cell cultures was achieved followed by virus suspensions. In order to determine the $\mathrm{TCID}_{50} / \mathrm{ml}$ titers of PK-CE1, O-CEV1, O-CEV2, and O-CEV3 strains in FLK-BLV-044 cell cultures, $10^{-1}-10^{-6}$ serial dilutions in the PBS of CE viruses were used in 96 well plates (Greiner, Germany). From each dilution of the viruses, $100 \mu \mathrm{l}$ was placed in each 96 well plate, and $50 \mu 1$ of the FLK-BLV-044 cell culture $\left(3-5 \times 10^{5}\right.$ cells $\left./ \mathrm{ml}\right)$ was added to all dilutions. For cell control, $100 \mu \mathrm{l}$ of the medium and $50 \mu \mathrm{l}$ of the cell suspension were placed in the last four wells of the plate. The plate was incubated at $37^{\circ} \mathrm{C}$ at a $5 \% \mathrm{CO}_{2}$ condition and checked every day for 10 days. Formation of CPE due to the growth of viruses was observed. The titers (TCID $_{50}$ values) of the CE strains were determined by the end-point titration method and observation of the CPE. The TCID $_{50}$ was calculated $(9,22)$.

Pathogenicity studies. The sera of the animals in the experimental groups were tested for antibodies against the $\mathrm{CE}$ virus by the sera neutralization test (SNT). Three experimental groups were used in this investigation (Tab. 2).

Group 1. This group was a pathogenicity study in lambs with a CE virus isolated from kids. In this group, 12 lambs (each strain to every four animals) were inoculated with $0.1 \mathrm{ml}$ of the virus suspension of three CE virus isolates (O-CEV1, O-CEV2, and O-CEV3) after being mixed with PBS (50\%) + Glycerin (50\%), and two lambs received an application of only the 
Tab. 2. Implementation plan

\begin{tabular}{|c|c|c|c|c|}
\hline Groups & $\begin{array}{c}\text { Species } \\
\text { of animals }\end{array}$ & $\begin{array}{l}\text { Number } \\
\text { of animals }\end{array}$ & $1^{\text {st }}$ inoculum & $2^{\text {nd }}$ inoculum \\
\hline \multirow{8}{*}{ Group 1} & Kid & 4 & 0-CE1 & - \\
\hline & Kid & 4 & 0-CE2 & - \\
\hline & Kid & 4 & 0-CE3 & - \\
\hline & Kid & 2 & mock & - \\
\hline & Lamb & 4 & 0-CE1 & - \\
\hline & Lamb & 4 & O-CE2 & - \\
\hline & Lamb & 4 & 0-CE3 & - \\
\hline & Lamb & 2 & mock & - \\
\hline \multirow{2}{*}{ Group 2} & Kid & 4 & PK-CK1 & - \\
\hline & Kid & 2 & mock & - \\
\hline \multirow{7}{*}{ Group 3} & Kid & 4 & vaccine- & PK-CK1 \\
\hline & Kid & 4 & vaccine & 0-CE3 \\
\hline & Kid & 2 & vaccine & mock \\
\hline & Kid & 2 & mock & PK-CK1 \\
\hline & Kid & 2 & $"$ & 0-CE2 \\
\hline & Kid & 2 & $“$ & 0-CE3 \\
\hline & Kid & 2 & mock & mock \\
\hline
\end{tabular}

Explanations: Group 1 - Pathogenicity study in kids and lambs with CE virus strains isolated from kids; Group 2 - Pathogenicity study in kids with CE virus strains isolated from lamb; Group $3-$ Immunity study of vaccinated kids with $\mathrm{CE}$ virus strains

PBS + Glycerin mixture for negative control (mock) by the scarification method $(13,17)$.

Group 2. This group was a pathogenicity study in kids with a $\mathrm{CE}$ virus isolated from kids. In this group, 12 kids (each strain to every four animals) were inoculated with $0.1 \mathrm{ml}$ of virus suspension of three $\mathrm{CE}$ virus isolates (O-CEV1, O-CEV2, and O-CEV3) after being mixed with PBS $(50 \%)+$ Glycerin $(50 \%)$, and two kids received an application of only the PBS + Glycerin mixture for negative control (mock) by the scarification method $(13,17,30)$.

Group 3. This group was a pathogenicity study in kids with a CE virus isolated from lambs. In this group, four kids were inoculated with a $\mathrm{CE}$ virus isolate (PK-CK1) after being mixed with PBS (50\%) + Glycerin (50\%), two kids received an application of only the PBS + Glycerin

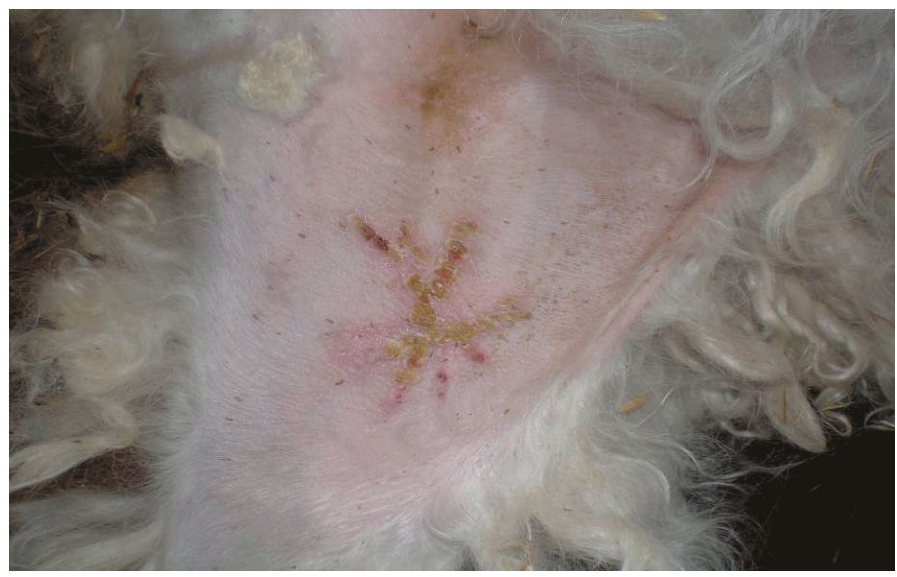

Fig. 1. Skin lesion of kid given the O-CEV1 strain on the $3^{\text {th }}$ day mixture for negative control (mock) by the scarification method $(13,17)$.

Group 4. In this group, kids were inoculated with the Penorf $C E$ vaccine and were challenged with three $C E$ virus isolates (O-CEV1, O-CEV2, and O-CEV3). The lyophilized Penorf CE vaccine was diluted with $40 \mathrm{ml}$ of $50 \%$ glycerin $+50 \%$ PBS reconstituted liquid. Fourteen kids were scarified with a needle deep enough to cross the first layer of the skin by crossing the hairless skin area of the hind limb in a $0.5-1 \mathrm{~cm}$ diameter with three or four lines. Three drops of diluted Penorf CE vaccine were dropped on the scarified areas, and the vaccinations were completed by waiting for three to four seconds (23). The body temperatures of the vaccinated animals were measured for 15 days. Skin areas were checked daily in terms of necrosis, hyperemia, and CE disease symptoms $(18,20,21)$. Eight (mock) kids were used as controls (mock), and two to four drops of PBS (50\%) + Glycerin (50\%) mixture were applied to the scarified area. Virus suspensions containing at least $\mathrm{TCID}_{50} 10^{3,2} / \mathrm{ml}$. from O-CEV1, O-CEV2, and O-CEV3 isolates were mixed with PBS + Glycerin and were applied to 12 kids for a challenge by the scarification method. The body temperature of the kids were measured for 15 days. Formations such as vesicles, pustules, and later crusting on the scarified areas of the skin of the vaccinated and control kids were observed for two months.

\section{Results and discussion}

Titers of vaccine virus $\left(\mathrm{E}(\mathrm{P}) \mathrm{CK}_{22}\right)$, PK-CK 1 , $\mathrm{O}-\mathrm{CEV} 1, \mathrm{O}-\mathrm{CEV} 2$, and $\mathrm{O}-\mathrm{CEV} 3$ strains produced in FLK-BLV-044 cell cultures were determined between $10^{5.75}-10^{7.00} \mathrm{TCID}_{50} / \mathrm{ml}$.

Pathogenicity studies in kids with CE kid isolates (group 1). In the pathogenicity studies of the O-CEV1, $\mathrm{O}-\mathrm{CEV} 2$, and $\mathrm{O}-\mathrm{CEV} 3$ virus strains in kids, there was no increase in the body temperatures of the kids (between $38.5-39.5^{\circ} \mathrm{C}$ ), and in the skin regions scarified with all three $\mathrm{O}-\mathrm{CEV}$ isolates hyperemia, vesicles and pustules occurred in the following days. The lesions were present for 38 days (Fig. 1), healing started on the $45^{\text {th }}$ day, and the scabs were shed on the $51-55^{\text {th }}$ days. On the $2^{\text {nd }}$ day of the eprüvation, small, narrow wound scabs were seen in the control kids. Afterwards it was

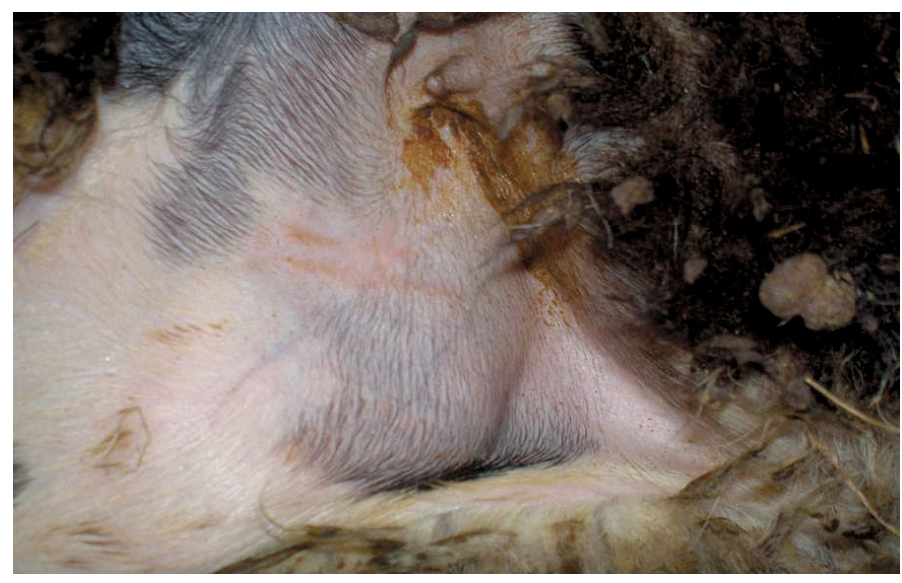

Fig. 2. Skin lesion of lamb given the O-CEV1 strain on the $38^{\text {th }}$ day 
observed that these small, narrow scars were shed on the fifth day, and there was no lesion on the skin.

Pathogenicity studies in lambs with CE kid isolates (group 2). The O-CEV1, O-CEV2, and O-CEV3 virus strains did not increase the body temperature in lambs (between $38.0-39.0^{\circ} \mathrm{C}$ ), and hyperemia occurred from the second day of epruvation on the skin regions scarred with the three O-CEV isolates. Vesicles, pustules and scabs were observed over the following days, and it was found that healing occurred in the lesions between the 36th and the $42^{\text {nd }}$ days (Fig. 2).

Pathogenicity studies in kids with the CE virus isolated from lambs (group 3). In this group, there was no increase in body temperature $\left(38.1-39.3^{\circ} \mathrm{C}\right)$ with kids with the CE field virus isolated from lambs (PK-CK1), and hyperemia occurred in the scarred skin areas, and vesicles and pustules occurred over the following days. Healing of the lesions started on the $42^{\text {nd }}$ day, and the scabs were shed between the $50^{\text {th }}$ and the $55^{\text {th }}$ days.

Immunity studies in kids (group 4). There was no antibody to the $\mathrm{CE}$ virus in the blood sera after vaccination in the kids vaccinated with the PENORF CE vaccine. In the epruvation study conducted to determine immunity against the PK-CK1 and O-CEV3 CE field isolates, it was observed that the lesions from the PK-CK1 and O-CEV3 isolates healed in a shorter period than the lesions detected in the pathogenicity studies. Antibody titers against the $\mathrm{CE}$ virus could not be detected by the SNT test in blood sera.

Molecular analysis of CE (ORF) field isolates of lamb and kid origin. After optimization of the sequence primers, bands were obtained by PCR using DNAs of the samples using four primer pairs selected for DNA sequencing (Fig. 3, 4, 5). Purified DNA samples were obtained from each PCR product (Fig. 6). After the comparison of the B2L genes of the CE (ORF) virus,

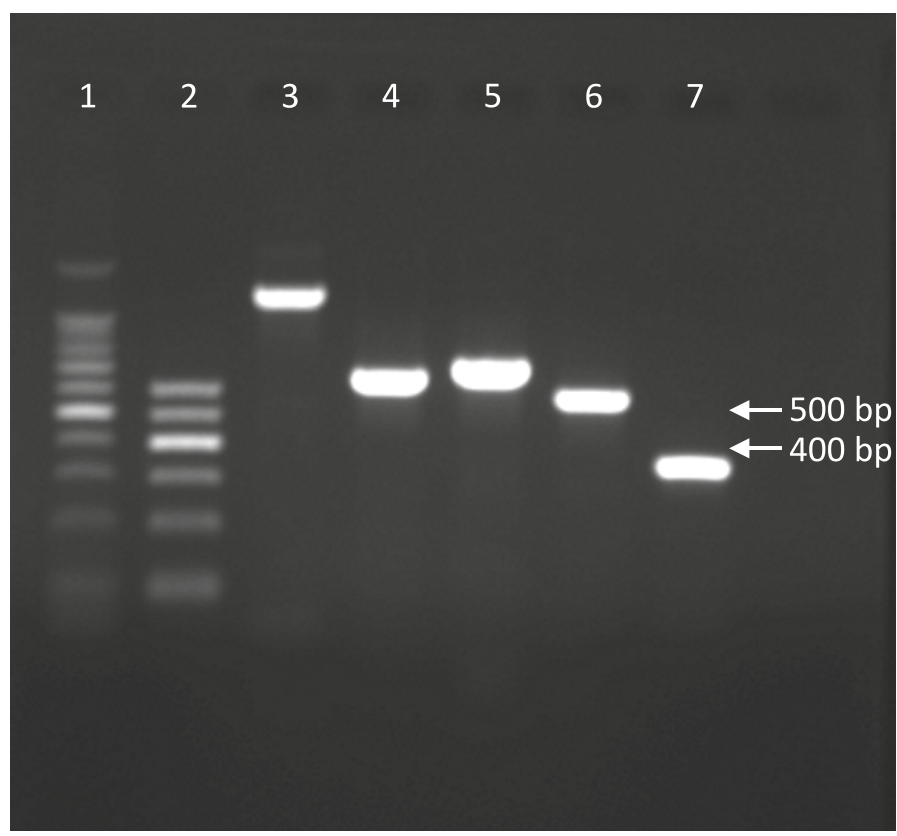

Fig. 3. Optimization

Explanations: 1 -DNA ladder (Promega 100 bp); 2 -DNA ladder (Qiagen $100 \mathrm{bp}$ ); 3 - Primers OVB2LF and OVB2LR (1206 bp); 4 - primers B2LF1 and B2LR2 (660 bp); 5 - primers B2LF2 and B2LR3 (713 bp); 6 - primers B2LF3 and B2LR4 (574 bp); 7 - primers B2LF4 and B2LR5 (346 bp)

Tab. 3. Possible original animal sources according to result of nucleotide and amino acid phylogenetic maps of reference genes

\begin{tabular}{|l|l|l|}
\hline \multicolumn{1}{|c|}{ Name of viruses } & \multicolumn{1}{|c|}{ Animal species } & \multicolumn{1}{c|}{$\begin{array}{c}\text { Results of phylogenetic } \\
\text { similarity }\end{array}$} \\
\hline E(P)CK ${ }_{22}$ (ORF1TR) & Lamb (vaccine strain) & Lamb \\
\hline PK-CK1 (ORF2TR) & Lamb (field isolate) & Lamb \\
\hline 0-CEV1 (ORF3TR) & Kid (field isolate) & Lamb \\
0-CEV2 (ORF4TR) & Kid (field isolate) & Lamb \\
\hline 0-CEV3 (ORF5TR) & Kid (field isolate) & Kid \\
\hline
\end{tabular}

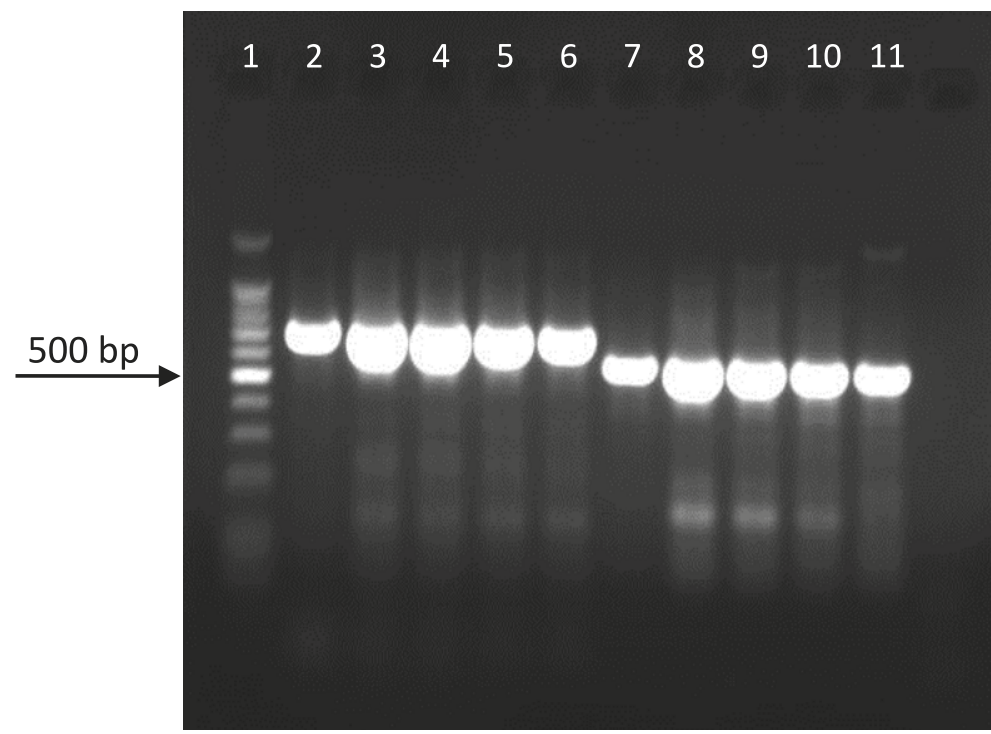

Fig. 4. PCR results of $C E$ virus strains

Explanations: 1 -DNA ladder (promega 100 bp); 2-6-PCR results made with B2LF2 and B2LR3 primers (713 bp); 7-11 - PCR results made with B2LF3 and B2LR4 primers

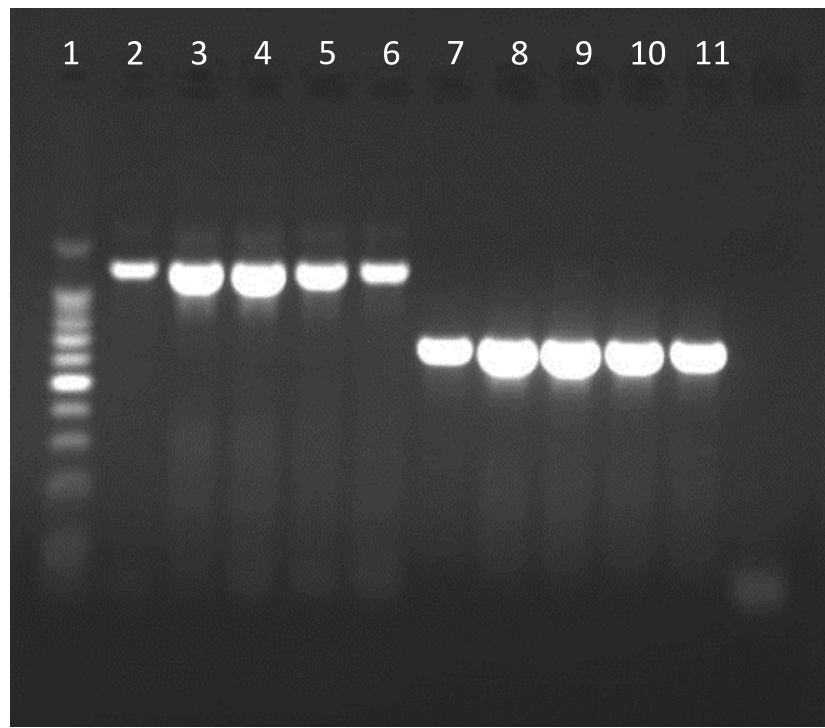

Fig. 5. PCR results of $C E$ virus strains

Explanations: 1: DNA ladder (promega $100 \mathrm{bp}$ ); 2-6 PCR results made with OVB2LF and OVB2LR primers (1206 bp); 7-11 - PCR results made with B2LF1 and B2LR2 primers $(660 \mathrm{bp})$ 


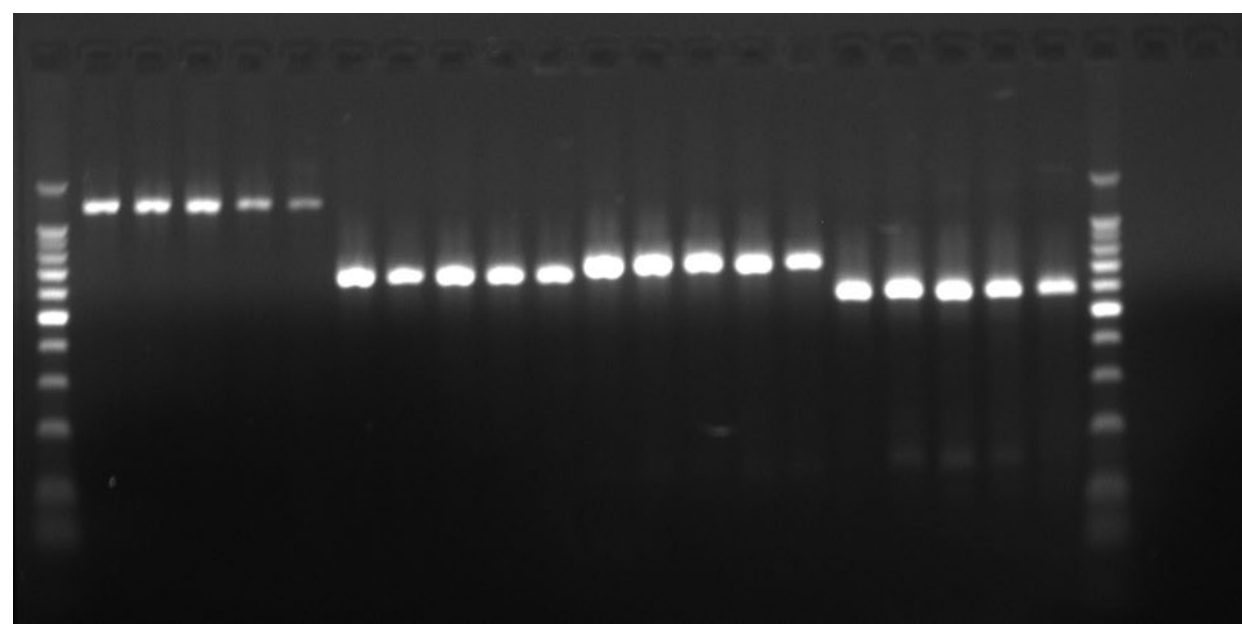

Fig. 6. Appearance of DNA bands after using DNA purification kit analysis of the molecular studies that we performed, it was found that, while the isolates had similar DNA sequences [O-CEV1 and O-CEV2 (100\%)], the other isolates, O-CEV3, showed different DNA sequences, and they differed $2.6 \%$ according to the similarity index. The vaccine strain and the lamb isolate used in the study were found to be among the kid isolates in the phylogenetic tree formed by a comparison of the results of the sequence analysis. In addition, in a study conducted in Turkey, it was reported that

the genes of sheep and goats were found to be more closely related to each other according to the similarity index between them (Tab. 3) (Fig. 7).

According to the results of the phylogenetic studies in the molecular studies, the isolates O-CEV1 (ORF3TR) and O-CEV2 (ORF4TR) had similar DNA sequences $(100 \%)$. The other isolates (ORF5TR) O-CEV3 showed different DNA sequencing, and the similarity index was found to be a $2.6 \%$ difference between them. As a result of phylogenetic analysis, it was found that the strains isolated from lambs were included in the goat group, and the O-CEV1 (ORF3TR) and O-CEV2 (ORF4TR) strains isolated from the kids were included in the sheep group (Fig. 7).

$\mathrm{CE}$ disease is seen in sheep and goats up to one year after birth. Vaccines used for prevention and control of $\mathrm{CE}$ infection are live attenuated, and are named according to the animal species from which they are isolated (1). The vaccine strain used for the CE infection was isolated from lambs, evaluated as a lamb strain, and began to be used by attenuating 30 years ago in Turkey. In recent years, strains isolated from lambs and kids were analyzed by molecular sequence analysis. According to the results of the phylogenetic different genotypes of CE viruses may be effective in $\mathrm{CE}$ infections that show clinical symptoms in different forms in lambs and kids. In this study, it was also reported that it is appropriate to investigate the genomic relationship between viruses that cause different forms (15). In the study we conducted, the first phylogenic evaluation revealed that different forms of disease can be seen in lambs and kids because the CE viruses detected in Turkey cannot be species specific and have genomic characteristics with different pathogenesis.

In this study, the titers of the $\mathrm{CE}$ vaccine virus originating from lambs $\left(\mathrm{E}(\mathrm{P}) \mathrm{CK}_{22}\right)$, the $\mathrm{CE}$ virus PK-CE1 strain isolated from lambs, and the O-CEV1, (O-CEV2) and (O-CEV3) strains isolated from kids were obtained between TCID $_{50} 10^{5.50}-10^{7.00} / \mathrm{ml}$ in the FLK-BLV-044 and was seen to be higher than the titers obtained by Ergin and Köklü (9); therefore, the FLK-BLV-044 cell culture was found to be sensitive for $\mathrm{CE}$ virus production.

Multifocal severe papillomatous proliferative skin lesions, hyperemia, macule papules, vesicles, pustules, and scabs were seen on the third or fourth day of pathogenicity studies in sheep and goats with CE field virus isolates $(7,29)$. In addition, it was determined that

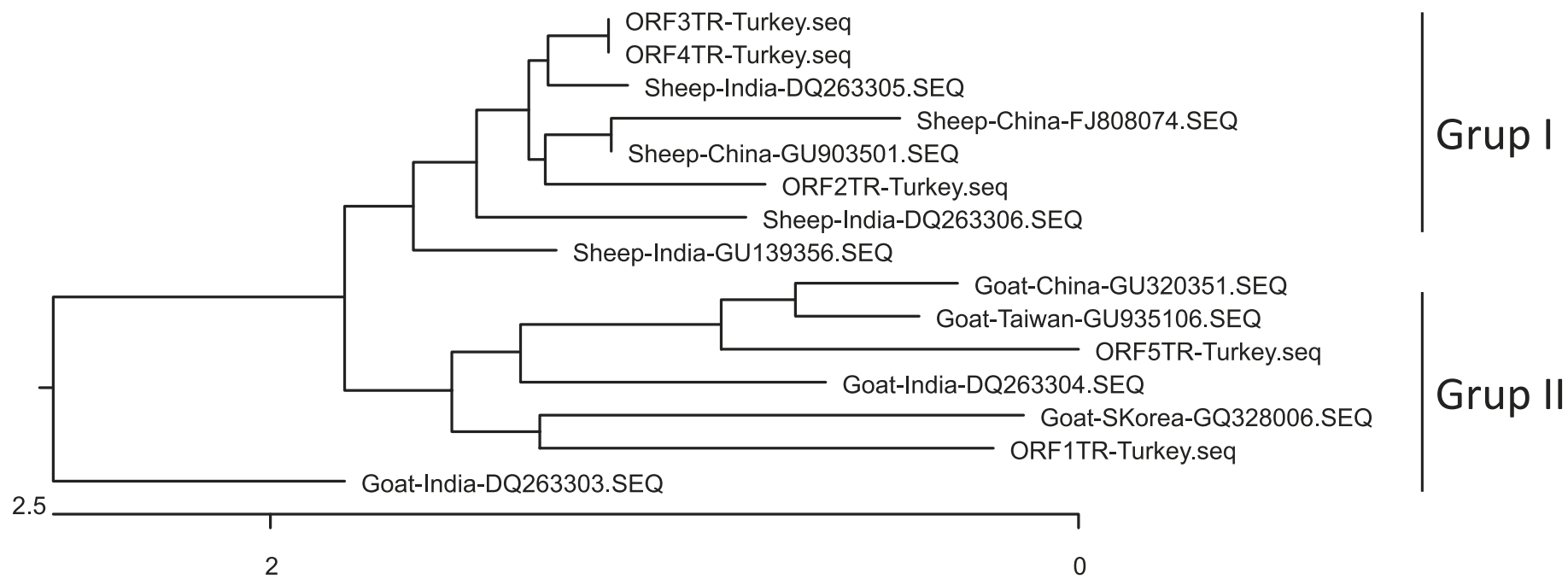

Fig. 7. Phylogenetic similarity map of the ORF virus after comparing the B2L genes 
neutralized antibody titers were not found in blood sera from animals with characteristic CE skin lesions (14, $25,29)$. In the immunity study we performed, in the eprüvation of the kids vaccinated with the Penorf CE vaccine, an immune response occurred to the O-CEV3 strains but not with the PK-CK1 lamb isolate. In addition, in our study the presence of antibodies to the $\mathrm{CE}$ virus could not be detected in the blood sera of the vaccinated and eprüvated animals as mentioned above $(25,29)$. This demonstrates the importance of cellular immune response in $\mathrm{CE}$ infection as revealed by other researchers $(2,11,29)$.

As a result, the phylogenic evaluation revealed that CE viruses were not species specific and have different genotypes in lambs and kids in Turkey. The Penorf vaccine strain, which is still known to be of lamb origin, was found to be of kid origin; therefore, it was concluded from this data that the bivalent $C E$ vaccine containing lamb and kid isolates should be prepared and used for effective immunity to CE infection, especially in lambs and kids.

\section{References}

1. Buddle B. M., Dellers R. W., Schuring G. G.: Heterogenicity of contagious ecthyma virus isolates. Am. J. Vet. Res. 1984, 45, 75-79.

2. Buddle B. M., Pulford H. D.: Effect of passively acquired antibodies and vaccination on the immune response to contagious ecthyma virus. Vet. Microbiol. 1984, 9, 515-522.

3. Burleson F. G., Chambers T. M., Wiedbrauk D. L.: Virologia Laboratory Manual. Academic Press. California 1992, 20-61.

4. Cargnelutti J. F., Masuda E. K., Martins M., Diel D. G., RockD. L., Weiblen R., Flores E. F: Virological and clinico-pathological features of orf virus infection in experimentally infected rabbits and mice. Microb. Pathog. 2011, 50, 56-62.

5. Chan K. W., Lin J. W., Lee S. H., Liao C. J., Tsai M. C., HSU W. L., Wong M. L., Shih H. C.: Identification and phylogenetic analysis of orf virus from goats in Taiwan. Virus Genes 2017, 35, 705-712.

6. Coates J. W., Haff S.: Contagious ectyhma: an unusual distribution of lesions in goats. Can. Vet. J. 1990, 31, 209-210.

7. De La Concha-Bermejillo A., Guo J., Zhang Z., Waldron D.: Severe persistent orf in young goats. J. Vet. Diagn. Invest. 2003, 15, 423-431.

8. Demiraslan H., Dinc G., Doganay M.: An overview of orf virus infection in humans and animals. Recent Pat Antiinfection. Drug Discov. 2017, 12, 21-30.

9. Ergin H., Koklu A.: Investigation of tissue culture passage and antigenic properties of ectima virus. Pendik Vet. Mikrobiol. 1974, 6, 12-20.

10. Gameel A. A., Abu Elzein E. M. E., Housawi F. M. T., Agip A., Ibrahim A.: Clinico-pathological observations on naturally occurring contagious ecthyma in lambs in Saudi Arabia. Revue Elev. Med. Vet. Pay. Trop. 1995, 48, 233-235.

11. Haig D. M., Melnnes C. J.: Immunity and counter-immunity during infection with the parapoxvirus orf virus. Virus Research 2002, 88, 3-16.

12.Hosamani M., Bhanuprakash V., Scagliarini A., Sing R. K.: Comparative sequence analysis of major envelope protein gene (B2L) of Indian orf viruses isolated from sheep and goats. Vet. Microbiol. 2006, 116, 317-324.

13. Housawi F. M. T., Abu Elzein E. M. E., Gameel A. A., Ala Faleg A. I.: A Close comparative study on the response of sheep and goats to experimental orf infection. J. Vet. Med. 1993, 40, 272-282.

14. Hussain K. A., Burger D.: In vivo and invitro characteristics of contagious ecthyma virus isolates: host response mechanism. Vet. Microbiol. 1989, 19, 23-36.

15. Issi M., Gulacti I., Bulut H., Gul Y.: Severe Persistent Contagious Ecthyma Cases in Twin Goats. J. Anim. and Vet. Adv. 2010, 9, 2477-2481.

16. Mazur C., Ferreira I. I., Rangel F. B., Galler R.: Molecular characterization of Brazilian isolates of orf virus. Vet. Microbiol. 2000, 73, 253-259.

17. Mckeever D. J., Jan Kinson D. M., Hutchison G., Reid H. W.: Studies of the pathogenesis of orf virus infection in sheep. J. Comp. Pathol. 1988, 99, 317-328.

18. Mckeever D. J., Reid H. W., Ingus N. F., Herring A. J.: A qualitative and quantitative assessment of the humoral antibody response of the sheep to orf virus Infection. Vet. Microbiol. 1987, 15, 229-241.
19. Mondal B., Bera A. K., Hosamani M., Tembhurne P. A., Bandyopadhyay S. K.: Detection of orf virus from an outbreak in goats and its genetic relation with other parapox viruses. Vet. Res. Commun. 2006, 30, 531-539.

20. Musser J. M. B., Taylor C. A., Gua J., Tizard I. R., Walker J. W.: Development of a contagious ecthyma vaccine for goats. Am. J. Vet. Res. 2008, 69, 1366-1370 .

21. Musser J. M. B., Waldron D. F., Taylor C. A.: Evaluation of homologous and heterologous protection induced by a virulent field strain of orf virus and an orf vaccine in goats. Am J. Vet. Res. 2012, 73, 86-90.

22. Nashirudddullah N., Pathak D. C., Barman N. N., Ahmet J. A., Raibongshi G., Sharna R. K., Borah P., Begum S. S.: Evaluation of orf virus (ORFV) isolation in continuous lamb testis cells (OA3.Ts) and development of a co-culture method with infected cells to increase infectivity. Indian J. Anim. Res. 2016, 50, 951-957.

23. Nettleton P. F., Brebner J., Pow I., Gilray J. A., Bell G. D., Reid H. W.: Tissue culture-propagated orf virus vaccine protects lambs from orf virus challenge. Vet. Record. 1996, 138, 184-186.

24. Peralta A., Robles C. A., Juan F., Micheluod J. F., Rossanigo C. E., Martinez A., Carosio A., König G. A.: Phylogenetic analysis of orf viruses from five contagious ecthyma outbreaks in Argentinian goats. Front. Vet. Sci. 2018, 5, 134

25. Pye D.: Vaccination of sheep with cell culture grown orf virus. Aust. Vet. J. 1990, 67, 182-183.

26. Rabinson A. J., Balassu T. C.: Contagious pustular dermatitis (Orf). Vet. Bull. 1981, 51, 771-782.

27. Rafii F., Burger D.: Comparison of contagious ecthyma virus genomes by restriction endonucleases. Arch. Viral. 1984, 84, 283-289.

28. Seifert H. S. H.: Contagious ecthyma (CE) orf. Tropical Animal Health, Kluver Academic Publish, Dordrecht 1996, p. 402-403.

29. Yirrell D. L., Reid H. W., Norval M., Idowie S. E. M.: Immun responses of lambs to experimental infection with orf virus. Vet. Immunol. Immunopathol. 1989, 22, 321-322.

30.Zamri S. M., Rashidah I., AL-Ajeeli K. S. A.: Experimental cross-infection of sheep and goats with different isolates of contagious ecthyma virus. Aust. Vet. J. 1994, 71, 218-220.

31. Zhao K., He W., Gao W., Lu H., Han T., Li J., Zhang X., Zhang B., Wang G., $S u$ G., Zhao Z., Song D., Gao F.: Orf virus DNA vaccines expressing ORFV 011 and ORFV 059 chimeric protein enhances immunogenicity. Virol. J. 2011, 8,562

Corresponding author: Veli Gülyaz, Assoc. Prof. Dr. DVM, Ministry of Agriculture and Forestry, General Directorate of Food and Control, Dumlupınar Bulvarı, No:161, 06800, Çankaya, Ankara, Turkey; e-mail: veli.gulyaz@tarimorman.gov.tr; veligulyaz@yahoo.co.uk 